\title{
THE MATERIAL RESIDUE. KANT AND HUSSERL ON AN ASPECT OF THE TRANSCENDENTAL FOUNDATION OF THE SCIENCE OF NATURE
}

\section{FRANCESCO PISANO}

\author{
M. A. in Philosophy. \\ University of Naples “Federico II”, Department for the Humanities. \\ 80133 Naples, Italy. \\ E-mail: francesco.pisano333@gmail.com
}

Husserl's late claim of that transcendental logic is self-founded stands in a puzzling relation with the facticity of nature. This relation concerns issues such as the traceableness of a "living present" in the immanence of living consciousness. The article considers this matter through a specific perspective, gained by reference to the project of a transcendental foundation of the science of nature. This project requires the problematic possibility of a formal determination of facticity. One could characterize the phenomenological finding of a "living present" as Husserl's attempt to resolve the discrepancy between fact and form in a "living being" which consists of both actual materiality and transcendental ideality. This conciliatory solution remains questionable, given the impossibility to provide an a priori foundation of this synthetic moment through the self-reflexive movement of transcendental logic. However, the systematic project of transcendental phenomenology as such entails the question concerning the a priori foundation of our ordinary knowledge of facts. It seems, then, to require a solution of this sort. The problem of grounding the scientific knowledge of natural facts dates back at least to Aristotle's Posterior Analytics. So does the need for the definition of an empirical moment of this grounding. A discussion of Kant's Metaphysische Anfangsgründe der Naturwissenschaft presents an aporetic facet of the way in which transcendental philosophy responds to this need. An analogous impasse occurs in Husserl's mature work. The concept of "living present" holds a central role in defining Husserl's stance towards this stalemate. The analysis of this role aims to clarify both Husserl's specific position in the broader context of transcendental philosophy, and an aspect of the transcendental foundation of the science of nature. I conclude that this foundation must encompass a factual, non-formalizable element: a material residue, required in order to complete its reflexive movement.

Key words: Phenomenology, transcendental philosophy, philosophy of science, science of nature, a priori, living present, Kant, Husserl.

Acknowledgements. First, I would like to extend my special thanks to PD Dr. Fausto Fraisopi, whose kind encouragements contributed greatly in making this research possible. Moreover, I would like to express my gratitude to Prof. Dr. Hans-Helmuth Gander, Director of the Husserl-Archiv Freiburg, for granting me the permission to consult Husserl's unedited manuscripts. I would then like to thank Dr. Michela Summa, $\mathrm{PhD}$, and Dr. Martina Lauren Roneker, for their philosophical and linguistic advices.

(C) FRANCESCO PISANO, 2018 


\title{
МАТЕРИАЛЬНЫЙ ОСТАТОК. КАНТ И ГУССЕРЛЬ О ПРИНЦИПАХ ТРАНСЦЕНДЕНТАЛЬНОГО ОСНОВАНИЯ НАУКИ О ПРИРОДЕ
}

\author{
ФРАНЧЕСКО ПИЗАНО
}

\author{
Магистр философии. \\ Университет Неаполя «Federico II», кафедра гуманитарных наук. \\ 80133 Неаполь, Италия. \\ E-mail: francesco.pisano333@gmail.com
}

Попытки позднего Гуссерля осуществить само-обоснование трансцендентальной логики сами оказались в запутанном отношении с фактичностью природы. Это относится к таким аспектам, как «живое настоящее» в имманентности живого сознания. В статье этот вопрос рассматривается через специфическую перспективу с отсылкой к проекту трансцендентального основания науки о природе, для которого необходимо проблематизировать возможность формального определения фактичности. Введение феноменологического понятия «живого настоящего» можно трактовать как попытку Гуссерля разрешить несоответствие между фактом и формой в «жизни», которое заключается в актуальной материальности и трансцендентальной идеальности. Такой способ примиряющего решения остается под вопросом, поскольку невозможно гарантировать априорное обоснование синтетического момента через само-рефлексивную направленность трансцендентальной логики. В тоже время систематический проект трансцендентальной феноменологии как таковой заключает в себе вопрос об априорном основании нашего обыденного знания фактов. По всей видимости, все же возникает необходимость искать решение для проблемы такого рода. Проблема обоснования научного знания природных фактов отсылает нас к тексту Аристотеля Вторая аналитика. Тем самым указывается на необходимость определения эмпирической составляющей такого обоснования. Рассмотрение работы Метафизические начала естествознания демонстрирует апоретичность способа, которым трансцендентальная философия может обосновать такую необходимость. Схожее impasse появляется в последней работе Гуссерля. Понятие «живого настоящего» играет центральную роль при обосновании позиции Гуссерля в отношении этой безвыходной ситуации. Осуществленный анализ этой роли позволяет прояснить как специфическую позицию Гуссерля по отношению к более широкому контексту трансцендентальной философии, так и аспект трансцендентального обоснования науки о природе. Я прихожу к выводу, что такое обоснование должно включать фактичный, неформальный элемент: материальный остаток, необходимый для завершения рефлексивного движения.

Ключевые слова: Феноменология, трансцендентальная философия, философия науки, наука о природе, живое настоящее, Кант, Гуссерль.

Благодарность: Прежде всего мне хотелось бы выразить глубокую признательность приват-доценту д-ру Фаусто Фрайзопи, чья заинтересованность в совместной работе способствовала осуществлению данного проекта. Кроме того, мне хотелось бы выразить свою благодарность проф. д-ру Хансу-Хельмуту Гандеру за любезно предоставленную мне возможность работы с неизданными манускриптами Гуссерля. Я хотел бы поблагодарить д-ра Микелу Сумма, $\mathrm{PhD}$, и д-ра Мартину Лаурен Ронекер за их помощь как в философских, так и лингвистических вопросах. 


\section{INTRODUCTION}

The penultimate chapter of Kant's Kritik der reinen Vernunft (Kant, 1904) is, as it is well known, dedicated to the draft of an architectonic of pure reason as the system of philosophy. Such a system would have to subsume the manifold of knowledge derivable from pure reason under a single idea (Kant, 1904, 538): the idea of pure philosophy - that is, philosophy of pure reason. According to Kant, pure philosophy should include two aspects: a propaedeutic one (critical philosophy) and an expository one (metaphysics). The latter should exhibit the entirety of possible a priori knowledge as a system. This system should encompass both a priori knowledge of everything that is, and a priori knowledge of everything that must be. Namely, with respect to the former, this complex of a priori knowledge should consist of both a priori knowledge of the disposition of reason towards possible objects in general and a priori knowledge of given objects as a whole (as long as it is obtainable). Kant defines this whole as "nature", and the network that links together these two domains of a priori knowledge as "metaphysics of nature" (Kant, 1904, 546). This knowledge pertains then both to de jure possible objects and to de facto given objects, and thus constitutes the horizon of all theoretical a priori knowledge.

This architectonic outline, which remains substantially unaltered in the two editions of the Kritik der reinen Vernunft (Kant, 1781, 832-851; Kant 1904, 538-549), entails a specific relation between transcendental philosophy and the concept of nature as the whole of given facts. Therefore, it is a possible starting point for an attempt at clarifying an issue concerning the idea of a transcendental foundation of our positive knowledge of nature.

Let us examine this relation. Usually, positive knowledge is defined as the knowledge of an object as actually existing, i. e. as the knowledge of a fact. This definition embraces both our ordinary actual perceptive cognition and the wide variety of sciences that are in any way based on it. This complex of experiences - namely, the complex of positive knowledge - finds its formal unity in the positivity of its objects. Vice versa, one could delimit nature as the field of the objects of positive knowledge. Positive knowledge depends, then, on the actual occurrence of a perception. It is therefore contingent, just as its objects. It follows that nature could also be defined as the general ambit of contingent objects. On the other hand, the system of pure philosophy should consist only of necessary relations. More specifically, from the point of view of transcendental philosophy, these relations should systematically define the a priori principles of theoretical and practical reason. As a system, transcendental philosophy should then include "the laws of nature" (Kant, 1942, 202). Given the discrep- 
ancy between the contingency of facts and the necessity of a priori laws, this inclusion proves evidently problematic. Ultimately, it calls into play the enigma of the relation between form and matter within the transcendental constitution of the natural object.

This recapitulation of well-known issues, albeit schematic, presents the way in which transcendental philosophy poses the traditional problem of the relation between facts and ideas. The main aim of this article is to clarify a common aspect of Kant and Husserl's approach to this problem, in order to highlight a characteristic limitation of transcendental reflection in this regard. This clarification could contribute to offer a theoretical justification of the usual ascription of both thinkers to the same tradition of thought. Moreover, it could provide a clearer understanding of the tradition of transcendental philosophy as a whole. We will find that both Kant and Husserl's propositions concerning the foundation of positive science need to imply a moment in which the discrepancy between matter and form is reconciled; and that this reconciliation cannot be justified by transcendental reflection. In light of these remarks, the possibilities of transcendental philosophy should be at least partially redefined by the impossibility to absorb matter into form and vice versa.

Kant defines transcendental reflection as the act of connecting a synthesis of representations with the corresponding cognitive faculty, and thus as the act of distinguishing different syntheses based on the faculty that made them possible (Kant, 1904, 215). A transcendental reflection on a natural object should then be able to discriminate between "the determinable in general" and "its determination" (Kant, 1904, 218) - i. e., between matter and form, based on the corresponding cognitive source. The claim to a transcendental foundation of the science of nature must be fulfilled through such a reflection. This foundation should consist in a knowledge of a priori, non-factual determinations that nevertheless constitute facts as objects of positive knowledge. These determinations are then to be found only on the basis of the preliminary distinction between form and matter: they are a priori rules defining the respective synthetic faculties. It follows that a transcendental foundation of the science of nature should consist in the definition of certain conditions of legitimacy concerning the syntheses that constitute its objects.

The connection between the two aforementioned facets of metaphysics of nature is indeed hierarchic: transcendental philosophy (Kant, 1904, 547) guarantees the possibility of rational physiology. The latter, in turn, defines the conditions under which the scientific knowledge of a natural object is legitimate as such. The equivalence between foundation and definition of the conditions of legitimacy is indeed an aspect of the specific relevance of the Kritik der reinen Vernunft in the history of the problem regarding the knowledge of nature. 
The exposition of Kant's perspective on this problem should serve exactly the purpose of outlining this specificity - viz., the specific position of transcendental reflection in the general framework of the problem. This position is characterized by the structural connection of every formal determination to a determinable (matter), which can never be positively determined per se. Thus, a "material residue" should be defined as a residue of that, which is determinable. Matter is, by definition, the contingent aspect of the object of actual knowledge. It follows that the claim to a universal determination of contingency can be fulfilled only through the absorption of the determinable in the determination, and thus only through the dissolution of the difference (between matter and form) that opens up the space of transcendental reflection. Both Kant's concept of the essential mobility of matter and Husserl's concept of living present will be presented as ways to dissolve this difference.

This analogy should highlight that both proposals develop within the possibilities (and the limits) of transcendental reflection. Nevertheless, it should also underline the differences between Kant and Husserl's conceptions of this reflection. The notions of mobile matter and living present mean, respectively, a static determination and an active intuition. This dissimilarity mirrors the divergence between Kant's definition of transcendental reflection as the act of connecting representation to a static articulation of cognitive faculties, and Husserl's idea of the same act as the exploration of the structural field of possibilities that specifically defines each constitution of an intentional object.

We have outlined the argument and its aims. Let us now proceed to the actual examination of the issues we brought into play.

\section{THE PROBLEM OF FOUNDING THE SCIENCE OF NATURE}

The characterization of transcendental philosophy's specific perspective on the problem of the foundation of the science of nature requires, at least, a general understanding of the history of the problem. It is evident that, at least since Aristotle's exposition of the issue in the Posterior Analytics (Aristotle, 1831, 71-72), the scientific value of empirical knowledge of facts must rely on a non-empirical aspect: a principle, the truth of which is assured through immediate self-evidence rather than through empirical verification. Only by way of a relation with such universal and evidently true knowledge, one can recognize empirical statements as belonging to a stable network of propositions, and thus to the tissue of deductive inferences this network consists of. Such is the structure of the domain of scientific knowledge. Vice versa, the claim of acquiring a stable theoretical grasp of nature (i. e. of what there factually 
is) through such formal, non-empirical articulation of its inordinate factual variety, while on the one hand refers to the self-evident truth of a unity principle, on the other must somewhat require a certain "disposition" of form towards the facticity of nature. This notion of disposition is obviously vague. Nevertheless, just as such, it indirectly means a plexus of issues that remains constant into a well-defined history.

One could summarise the first of these issues in what follows: a principle, even if not empirically demonstrable (in other words, even if not observable as a derivation from another fact), should ideally share a common horizon with every particular empirical statement, as long as it provides the foundation - and thus, the scientific truth - of that particular statement. Aristotle's work responds to this need by the definition of this horizon as causality. Facts consist of a series of causal relations, and principles of each positive science should express the first of these causes for each thematic series of causally intertwined phenomena. Aristotle's Physics attempts indeed to give, through the study of the first causes of nature and of change in general, the explanatory resources required for an empirical and scientific investigation of the world of facts (Falcon, 2005, 1-16) ${ }^{1}$. This common ground should define the way in which one could bring the variety of facts back to scientific unity. Such a ground is required in order to ensure the intelligibility of the relation between particular facts and universal principles. Therefore, every attempt at a foundation of natural science demands a certain amount of abstraction: in each case, the variety of facts has to be unified by virtue of a distinction between essential and non-essential properties (Bunge, 1967, $51-72)$.

It seems that the traditional notion of natural science (empirical content in a non-empirical, formal order) implies that the essentially non-empirical principles, which superintend this order, must exhibit an empirical moment. One could define such a moment as a trait that pertains to facts in general and that, abstracted from them, gives us access to a knowledge of the form, of the unity of our thematic object - because, in fact, our scientific knowledge begins with experience. From a theo-

1 Falcon underlines how carefully structured Aristotle's inquiry on nature is. It begins with Physics, then proceeds through the study of celestial phenomena, and ends with an examination of the sublunary world. The unity of this investigation depends on the internal causal unity of its complex object (Falcon, 2005, 16). We said that Physics describes the first causes. This means that it describes the universal causal determinations pertaining to the domain of nature. As long as these determinations define nature as a whole, they cannot be justified, in their turn, by physics alone - being that physics presupposes the definition of its object. Falcon's study focuses on the internal coherency of Aristotle's conception of nature. We will instead aim attention at the need for a definition of nature that does not rely on positive knowledge alone. This need emerges within every attempt at establishing a system of scientific knowledge, as Aristotle's example is intended to show. 
retical point of view, even knowledge of the non-empirical must be obtained through a process that springs from the fact of experience.

These considerations are purposely generic: what is relevant for our argument is not the specific way in which Aristotle deals with the problem, but the fact that the very first theoretical outline of science as a systematically articulated unity seems to imply such an issue. As long as the idea of prima philosophia is relevant, the question arises of how a knowledge can be stable and related to facts at the same time. The puzzling connection between empirical and non-empirical aspects of the founding principles of positive science appears, in this context, as the explanandum. The relevance of the Architectonic of pure reason and, more generally, of every transcendental take on the issue, therefore follows from the way transcendental reflection intends the role of Grundsätze. In short: inasmuch as form is no more a real property, but rather the field of legitimacy of a possible Sinngebung, the common ground between facts (as objects of experience) and forms (as structures of the transcendental synthetic operativity from which the experience emerges) is the possibility of being thought as such (i. e., intelligibility in general).

A historical take on this matter would have to deal with the certainly relevant modifications of concepts such as causality and knowledge between Aristotle, Kant and Husserl. However, the following considerations will only concern a theoretical hypothesis. One can perhaps sum up this hypothesis as follows: if the consideration of nature within non-transcendental perspectives requires an abstraction from other real properties, in the context of transcendental philosophy the residue of this abstraction is instead the facticity of things as such. This facticity is to be understood as opposed to the results of the constitution of logical elements (or objects) that is implied in the operations of a priori transcendental consciousness.

\section{MATTER AND MOVEMENT}

Kant's philosophy of nature embodies the first and perhaps most emblematic example of the way in which transcendental philosophy deals with the matter at hand. Let us examine an aspect of how the project outlined in the Architektonik der reinen Vernunft unfolds. Kant's Metaphysische Anfangsgründe der Naturwissenschaft (Kant, 1911, 465-565) should have contained, according to that draft, rational immanent physiology: i. e. the metaphysics of empirical knowledge. Actually, in that work (published in 1786), Kant radically revises the structure and the position of this part of metaphysics in relation to the system. In fact, this remains the only part of metaphysics of nature that Kant realizes. 
Clearly, Kant's philosophy of nature crosses, in its long development, nearly all of its major philosophical writings, from Monadologia physica (Kant, 1902, 473-488) to Opus postumum (Kant, 1936; Kant, 1938). The dialogue with the historical development of physics is, in these writings, constantly open - the Vorrede to the second edition of the Kritik der reinen Vernunft being the most prominent example of a way of connecting physics and metaphysics that remains as a stable feature of Kant's philosophy. In general: if physics, as a science, presupposes metaphysical principles, then metaphysics, reformed in a critical sense, has to draw its observations first and foremost from the facts that physics exposes (Pecere, 2009, 3-33) 2 .

However, perhaps it is in the work of 1786 that this mutual implication becomes most clear: the claim to develop a traditional, Wolffian system of philosophy begins here to dissolve, giving way to a more complex movement of rebound between principles and facts. Immanent physiology reduces itself to rational physics. For its part, rational physics becomes profoundly intertwined with mathematics (i. e. to the science of constructing objects in the field of pure intuition, such as to allow us to anticipate, so to say, what is essentially given through sensibility), as long as it consists in an attempt to define an a priori knowledge pertaining determinate given facts. Such anticipation is impossible solely through concepts: the property one needs to anticipate while attempting at an a priori consideration of certain natural determinations is a property defined in the horizon of intuition. Concepts can only illustrate the formal possibility of an object, its mere intelligibility, whereas one can demonstrate the possibility of its existence (as long as it implies factual givenness) only through the presentation of an intuition corresponding to the concept - that is, through the construction of the concept in the horizon of pure intuition (Kant, 1911, 470).

It follows that a pure science pertaining to a determinate natural object can be defined as "pure" only insofar as it contains mathematics. Thus, rational (i. e. pure) physics is possible only as far as physical objects are mathematizable. Kant's constructivist take on mathematics (Hintikka, 1992, 21-23) allows the intelligibility of every mathematical object in the context of pure a priori intuition. On the other hand, Kant defines the object of physics in general as "matter" or "corporeal nature" (Kant, 1911,

2 The critical metaphysics of corporeal nature developed in Kant's MAdN explicitly occupies a sort of midpoint between positive physics and the metaphysical part of the philosophy of pure reason. Pecere details various aspects of its specific role in the system of transcendental philosophy. This role already takes into account a certain concession to the empirical concept of matter (Pecere, $2009,393-411$ ). From the point of view of transcendental philosophy, this concession is not a problem in itself, as long as the claim to an a priori foundation of nature is correspondently limited. A problem perhaps arises if the limited object of such an examination - movement, in the present case - is redefined as its essence, i. e. as a formal determination of the whole of factual nature. 
472). Therefore, rational physics would have to deal specifically with the mathematizable aspect of matter. The mathematizability of a determinate natural fact should indeed imply the possibility of an a priori definition of its existence.

Let us consider the text. The first definition of Phoronomie states that:

Matter is the movable in space. That space which in itself its movable is called material, or also relative space; that in which all motion must finally be thought (and which is therefore absolutely immovable) is called pure, or also absolute space. (Kant, 2004, 15; Kant, 1911, 480)

Matter is, essentially, what is mobile in space. Pure space is the horizon of every possible movement: it is not mobile, and thus not material. This dual definition already entails the operation of abstraction required to gain a pure knowledge of nature. In fact, reducing materiality to mobility means qualifying the essence of matter as measurable and thus quantizable. By Kant's perspective, quantities are both objects of philosophy and mathematics, while qualities can be examined a priori only through concepts, i. e. philosophically (Kant, 1904, A 714). This is because, while qualities are de facto given only through empirical intuition (to say, through an intuition that effectively applies to a sensation), determinate quantities, both continuous and discrete, can be constructed a priori, as long as one can associate a pure intuition to their concept. By means of pure intuition, individuals become possible objects of thought without compromising themselves with the contingency of facts: as long as an examination through concepts alone can only take into account more or less extensive generalities, such individual objects can only be mathematical ones.

In the first note to the definition, Kant seems to refer to the reduction of matter to movement as a characteristic feature of Phoronomie, which indeed focuses on movement (Kant, 1911, 480). He recognizes that this abstraction implies an a priori consideration of matter as if it were only a mobile point in space, mathematically defined by its movement. However, such abstraction remains indeed as a premise of rational physics as a whole, being that all three other definitions of matter in the work of 1786 presuppose mobility. Dynamik defines matter as the mobile, insofar as it fills space (Kant, 1911, 496). Mechanik defines it as the mobile, insofar as it has motive power (Kant, 1911, 536). Finally, Phänomenologie defines matter as the mobile, insofar as it is an object of experience (Kant, 1911, 554). They all start indeed from a specification of the first definition of Phoronomie, thus presupposing that definition. Therefore, the attempt at a definition of an a priori knowledge regarding matter results, actually, in the definition of a priori truths regarding movement. However, the claim that movement is the essence of the empirical concept of matter remains 
unjustified. So does, consequently, the attribution of the findings of rational physics to factual matter as a whole.

This movement of abstraction constitutes the first concrete attempt at a transcendental foundation of natural science, beyond the mere draft that is the Architektonik der reinen Vernunft. The relation with that systematic outline gives to the first definition of Phoronomie a peculiar problematic character. In itself, the modern idea of physics does not necessarily imply an a priori foundation in the traditional sense: positive research can efficiently proceed by means of operative, circular definitions (Toraldo di Francia, 1981, 51-52). It follows that the idea of a model-based physics is not taken as per se problematic: the abstraction of certain aspects of reality could be sufficiently justified by its functionality - that is, by its actual effectiveness in relation to the explanatory and predictive aims of positive science. For its part, transcendental philosophy's a priori definition of matter in relation to objects in general (i. e., as the determinable) does not seem inherently puzzling, at least from an epistemological point of view. However, a problem arises when attempting to conform actual physics to the claims of a systematic development of such kind of philosophy. Such an attempt would indeed require the grounding of an abstract notion of matter within an a priori theory, thus assigning to the chosen model an essential primacy, rather than a functional one.

In the second note at the first definition of Phoronomie, Kant writes:

If I am to explicate the concept of matter, not through a predicate that belongs to it itself as object, but only by relation to that cognitive faculty in which the representation can first of all be given to me, then every object of the outer sense is matter, and this would be the merely metaphysical explication thereof. [...] Matter, as opposed to form, would be that, in the outer intuition, which is an object of sensation, and thus the properly empirical element of sensible and outer intuition, because it can in no way be given a priori. [...] Finally, I further remark that, since the movability of an object in space cannot be cognized a priori, and without instruction from through experience, I could not, for precisely this reason, enumerate it under the pure concepts of the understanding in the Critique of the Pure Reason; and that this concept, as empirical, could only find a place in a natural science, as applied metaphysics, which concerns itself with a concept given through experience, although in accordance with a priori principles. (Kant, 2004, 16-17; Kant, 1911, 481-482)

Considering the Architektonik der reinen Vernunft, one easily notices that Kant's idea of a system of philosophy shows a certain ambiguity, being that critical philosophy is characterized as propaedeutic to metaphysics, while transcendental philosophy is determined as a part of it. In this passage, we see an analogous uncertainty. The metaphysical definition of matter as the determinable - i. e. matter defined by its role in the transcendental constitution of an object in general - pertains to a priori 
knowledge only by a negative determination. Matter is the aspect of the object of knowledge that (unlike form) cannot be given a priori. Therefore, the legitimacy of an a priori positive determination the essence of matter (i. e., of matter in general), such as the one implied in the first definition of Phoronomie, remains unjustified. Indeed, it requires a certain concession to experience. The question is if such partiality towards experience - which mirrors the aforementioned abstraction of some features from the physical fact, in order to make an object of stable knowledge out of it is, in general, a priori justifiable in its turn. This a priori justification would in fact mean that mobility would have to assume towards the rest of facticity ${ }^{3}$ a sort of formal role. No matter what the contingent impact of sensation could bring to intuition, matter would always be determined as mobile, and thus unified under this determination.

The notion of matter required by rational physics seems to dissolve the bounds fixed by metaphysics. While the hierarchic structure of the system should imply the comprehension of matter as facticity of nature under the a priori definition of matter pertaining to objects in general, thus defining facticity only through a negative relation with the formal structure of knowledge, the claim to a pure physics must admit an exuberance of matter from this negative relation. It must admit a universal positive determination of facticity as a whole. The point of the system in which the critical exam of the possible a priori knowledge should connect to the knowledge of determined natural objects seems indeed to imply a divergence between transcendental philosophy and the critical distinction between matter and form.

However, if the same act of transcendental reflection is tied together with this critical distinction, it follows that every transcendental approach to the foundation of the science of nature has to accept that its claim to an a priori knowledge of nature has to be limited by a certain partiality. This partiality is implied by the fact that every determination of the experience of a natural object remains in a certain relation with the factual aspect that defines this object as natural (given that its contingency cannot be resolved in any way into an a priori determination). Thus, a universal a priori determination of nature can be found only outside of the domain of what is justifiable through transcendental reflection. That is, if the issue concerning the transcendental definition of mobility as the essence of matter has its roots not in a specific feature of Kant's conception of transcendental reflection, but rather in the general structure

3 In this context, the notion of facticity should be intended as a phenomenological tool of analysis. Its function would be to indicate the field of that knowledge of contingent determinations that can only be acquired a posteriori, or the field of knowledge of what could be otherwise (in accordance with the use of the word "faktisch" in (Husserl, 1976, 12)). 
of transcendental reflection as such. Let us try to understand if this is the case by considering the same problem within the context of another instance of transcendental philosophy - the instance embodied by Husserl's transcendental phenomenology.

\section{THE PHENOMENOLOGICAL INTUITION OF LIFE-WORLD AS FOUNDATION OF THE SCIENCE OF NATURE}

Much has been said about the relationship between Kant and Husserl, and thus about the role of Husserl as a transcendental philosopher in the traditional sense (Kern, 1964, 276-303). We initially accepted the traditional interpretation of Husserl's phenomenology as one of the most relevant and elaborated examples of transcendental idealism ${ }^{4}$, in order to explore its meaning. We will now try to determine if even within the context of a phenomenological transcendental reflection an a priori determination of facticity should imply the dissolution of the critical distinction between form and matter. If so, the inclusion of Kant and Husserl under the same tradition should result clarified as the sharing of a common limit of their theoretical gestures. An examination of the phenomenological investigation of the founding conditions of the science of nature could indirectly shed more light not only on the relationship on Husserl's reception of Kant, but also on an aspect of transcendental reflection as such.

Husserl's work has provided a certain philosophical framework for positive research, especially concerning mathematics and physics (Ryckman, 2005, 108-145) 5 . Amongst other Husserl's writings, one often intends Die Krisis der europäischen Wis-

4 This initial inclusion of Husserl's work in the domain of transcendental idealism can be justified by a quote from the Cartesianische Meditationen (Husserl, 1973). There, Husserl explicitly defines for the first time his phenomenology as a "transcendental idealism, though in a fundamentally and essentially new sense" (Husserl, 1973, 118). Our starting hypothesis was exactly that Kant and Husserl's philosophies can be understood as two specific instances within the common framework of transcendental idealism. However, such a connection between Husserl's philosophy and transcendental idealism remains only nominal, as long as it is not validated by a clarification of the structure of Kant and Husserl's theoretical operations. The historical examination of Husserl's reception of Kant cannot possibly suffice to present such a clarification, given that this reception is already part of Husserl's theoretical project. In view of this aim, a systematic approach to the issues discussed by both thinkers would be required. The second part of Kern's Husserl and Kant (Kern, 1964, 51-320) can be seen as a paradigm of this systematic approach.

5 Being especially concerned by Weyl and Becker's contribution to the philosophical elaboration of Einstein's theory of relativity, Ryckman's book centers on Husserl's Ideen I. One could argue that the aporetic outcome of the founding problem of the science of nature from a transcendental point is 
senschaften und die transzendentale Phänomenologie (Husserl, 1954) as a major reference, concerning this topic. However, the general terms of Husserl's later contribution towards a philosophical theory of positive science trace back right to the first attempts at a genetic phenomenological analysis. In fact, his later works present what one could summarize as a constructive take on the crisis of modern rationalism.

This attempt intertwines itself profoundly with the aim of genetic phenomenological analysis, insofar as it is an effort at defining a new scientific praxis oriented by the idea of a transcendental clarification of the life-world, from which every complex intentional objective constitution emerges. Such praxis is, primarily, a scientific one; and, as a central nucleus, it entails a new comprehension of the science of nature, as far as the clarification of life-world is ultimately a transcendental clarification of facticity as such (Heelan, 1987, 380-388).

Husserl's appeal to a new praxis is justifiable from a transcendental point of view only if the concept of life-world entails a formal knowledge of facticity - a knowledge that could guarantee an a priori foundation of science of nature. A meaningful passage from the Krisis reads:

It is not the life-world as such what we know best, what is always taken for granted in all human life, always familiar to us in its typology through experience? Are not all its horizons of the unknown simply horizons of what is just incompletely known, i. e., known in advance in respect of its most general typology? [...] And perhaps the scientificity (Wissenschaftlichkeit), which this life-world as such, in its universality, requires, is a peculiar one, one which is precisely not objective and logical but which, as the ultimately grounding one, is not inferior but superior in value. But how is this completely different sort of scientific discipline, for which the objective sort has always been substituted up to now, to be realized? The idea of objective truth is predetermined in its whole meaning by the contrast with the idea of the truth in pre- and extra-scientific life. This latter truth has its ultimate and deepest source of verification in an experience, which is "pure" in the sense designated above, in all its modes of perception, memory etc. [...] What is actually first is the "merely subjective-relative" intuition of prescientific world-life. (Husserl 1970, 124-125; Husserl, 1954, 127-128)

Beyond the traditional requirements of scientific objectivity, this intuition encompasses a knowledge that gives sense to natural, historical praxis - and does so as a firm and definite knowledge. In other word, this intuition defines a "Typik", a formal unity for facts, as long as they present themselves into the horizon of praxis. It

already implicitly present in the work of 1913 . However, in order to highlight the decisive character of this issue for the phenomenological project as a whole, we need to focus on the genetic issue of the origin of intentional life. Sure enough, it is especially within this issue that phenomenology has to deal with the question of what is given "before" the intentional determination as such (i. e., before the form). 
follows that this intuition consists in a formal, but dynamic background of living consciousness. As long as it remains a constitutively implicit intention, such background is indeed a foundation. It is an aspect of living consciousness, whose intentional content cannot be determined through its articulated relations with other acts (namely, founding acts of sensible perception), but only progressively clarified in the explication of the unending task of transcendental self-reflection.

We have already defined, at least provisionally, the relation of foundation from a transcendental point of view: foundation is what determines the possibility of that, which is founded, as an objective constitution of transcendental consciousness. Clearly, this is not the phenomenological concept of Fundierung, which has a distinct mereological character. The issue at hand concerns specifically the effort for a transcendental Begründung (Husserl, 1974, 230-238) of knowledge in a phenomenological context, rather than the idea of a phenomenological description as such. Therefore, we will not take into account, here, the descriptive formal ontology of nature outlined in the Logische Untersuchungen (Husserl, 1984, 296-300). Based on the quoted excerpt from the Krisis, one could indeed attribute to the subjective-relative intuition of life-world the role of a Begründung.

This intuition is what constitutes everyday praxis as such. It is not reducible to other intuitions, as all of them are moments of the practical-historical life that unfolds in its horizon. It appears as formal and thus stable, by considering that every intentional constitution, from the simplest to the most complex, is ultimately a moment of this unfolding. It is, then, the stable, formal field of every possible knowledge. It is the field that the phenomenological transcendental self-reflection attempts at bringing to light. It is worth noting that such an attempt can be phenomenologically justified only through a reference to facticity. Indeed, phenomenological reflection is a self-reflection exactly because reflection in itself is a fact, taking place in the actual (albeit infinitely clarifiable) horizon of the life-world. Still, its clarification would demand a sort of detachment from everyday cognitive experience, given that ordinary knowledge (i. e., ordinary cognitive praxis) already implicitly presupposes this intuition.

The fulfillment of such a clarification would imply a complete reintegration of concrete experience into the reflexive abstraction. It would then mean the nullification of that separation between the fact and the knowledge of the fact that made transcendental reflection possible in the first place. Actually, facticity seems to be just what transcendental reflection leaves behind in order to abstract an a priori knowledge from the fact of experience. If that is the case, then transcendental reflection has to pursue indefinitely an aim that cannot be fulfilled within its domain. One could 
also say that the ultimate completion of transcendental philosophy would mean its dissolution as a theory.

Husserl and Kant's conceptions of transcendental reflection seem to share this sort of tragic aspect. Walter Benjamin refers exactly to this feature in order to define transcendental philosophy as a whole (Benjamin, 1985, 34-38). Benjamin's suggestion gives us a theoretical criterion for distinguishing transcendental philosophy from other possible theories. The issue concerning the foundation of the science of nature gave us the possibility to test the relevance of this criterion. Sure enough, it should be relevant as long as it allows us to decide the soundness of Kant and Husserl's proposals from a transcendental point of view.

However, it also appears to hint at a clearer (negative) determination of the claim to a non-transcendental, universal knowledge. In phenomenological terms, this would be the claim to a universal knowledge about what does not constitutes itself within the field of experience: the claim to a universal knowledge about the Faktum. Husserl defines such a knowledge as metaphysical (Husserl, 1973, 181-182) ${ }^{6}$. The integration of facticity into the a priori knowledge of experience should then result either in silence (that is, in the muteness of mere facts) or in a metaphysical knowledge. It follows that the idea of a complete theoretical clarification of life-world should be characterized as metaphysical.

Here we will not discuss extensively if the notion of an infinite progress towards the exhaustion of the phenomenological explanandum - which remains, even according to Husserl, de facto impossible - is inherently metaphysical in its turn, as it is a fairly common topic of critical literature (Tengelyi, 2005, 487-498) ${ }^{7}$. We will instead focus on the metaphysical character of the notion of "living present" as a mean to fill the gap between the fact of living consciousness and the founding formal intuition of life-world, in order to make this intuition at least de jure possible.

6 According to Husserl, the "total science of the a priori" must entail metaphysics as the theory concerning "all the problems of accidental factualness, of death, of fate" (Husserl, 1973, 181-182). One could argue that the problems posed by death, fate, or in general by the contingency of facts, are already included under "the problems of accidental factualness".

7 Both in Kant and Husserl's work, the ultimate completion of the task of reason, albeit de facto impossible, is formally defined by infinitely determinable ideas. In other words, even if we cannot actually connect (or display) the infinite variety of actual representations (or intentional objectivities) in an actual representation (or vision) of the totality of possible objects, we ideally know how to move towards this goal. However, it is worth noting - as Tengelyi does - that Husserl's conception of the infinity is different from Kant's in a very relevant way. Kant's infinity is potential; Husserl's 


\section{LIVING PRESENT AND FACTICITY}

Kant and Husserl's attempts at defining a junction between our knowledge of facts and the system of transcendental philosophy show, as we have seen, a common impasse. Despite relevant differences between the two conceptions of the relation between form and matter, the shared pursuit of a transcendental a priori foundation of our knowledge of facts seems to incur in an unjustified "apriorification" of a posteriori determinations. Let us further elucidate this point.

Kant's idea of physical matter resulted in a cardinal example of an aporia concerning the hylomorphic structure of the object of knowledge within transcendental reflection. The non-empirical determination of matter as a whole implied in Kant's rational physics should consist of an unjustified separation between a certain formal (universal) essence of matter and a non-formalizable factual residue. The former term is metaphysical insofar as it implies an unjustified fusion between form and matter. This fusion should serve to guarantee a continuous passage between the two, thus bypassing the discrepancy between necessity and contingency. It is a metaphysical operation, as long as it consists in an arbitrary assumption of a determinate aspect of this contingency as its universal essence.

Husserl's concept of living matter implies this same operation. First, let us remember (albeit only vaguely) the role and development of the notion in Husserl's work. Living present (lebendige Gegenwart): this expression refers to an aspect of the temporality of living consciousness - an aspect that emerges from the genetic analysis of the passive syntheses from which temporality emerges. The first relevant use of the concept dates back to the Bernauer Manuskripte über das Zeitbewusstseins (Husserl, 2001, 140-141), within a context defined by Husserl's first attempts at a genetic analysis of intentional constitutions. However, the search for a foundation of time-syntheses implied a genetic aspect even in the previous phenomenological researches about inner time-consciousness (Husserl, 1969, 99-134). The specificity of

infinity is actual. Kant's infinity is the infinity of an infinite series of connected representations of the same object; Husserl's infinity is the infinity of an omnilateral perspective on the same object. In a certain sense, the claim to an a priori determination of facticity implicitly gives access to this completion, as the universal determination of what is determinable (should the transcendental philosopher give in to the metaphysical aspect of Kant and Husserl's solutions). Therefore, these two different conceptions of infinity should define the two different tasks that are implicitly delegated to the mobile matter and to the living present. As we have seen, the mobility of matter makes facticity into something that can be constructed through a synthesis of representations. We will see that the living present makes facticity into something that is always already exposed into an intuitable horizon of intentional relations (i. e., into a horizon of potential phenomenological perspectives). 
the notion of living present in comparison with the concepts of Urimpression and Strom relies in its peculiar link with transcendental subjectivity. This link remains only outlined in the earlier concepts of this original level of temporality. Then, at a later stage, living present is defined as the time of transcendental, original presence, which determines consciousness as constitutively intentional, i. e. open towards an irreducible transcendence - being nevertheless somewhat extended and streaming, fluently stretching itself in a self-grasping movement from which the ego emerges as an originally factual whole.

It is not the case, here, to proceed to a more thorough explanation of the concept as such, being that critical literature already exhaustively examined this matter too (Held, 1966, 61-137). However, it is interesting to note that, while on the one hand the living present has been intended as the time of absolute subjectivity, ideally (necessarily) self-present as intentional operativity (Derrida, 1993, 4-5), on the other the whole of this subjectivity seems to exhibit only a factual (contingent) unity. Husserl recognizes that the wholeness of the intentional ego - the unity that, in Cartesianische Meditationen, he calls "monadisch konkrete ego" (Husserl, 1973, 102) — is indeed factual, as far as it implies that the hyletic aspect of intentional constitutions should be already included in this conclusive synthesis.

There are two main points to be clarified: if this intertwining between ideality and factuality implies a metaphysical continuity, rather than a mere contiguity; and how this supposedly transcendentally unjustifiable continuity is connected to the founding intuition of life-world. It is perhaps useful, in this regard, to explore Husserl's unpublished works (which, as it is known, constitute the larger part of his written production).

Here, we will briefly consider parts of a currently unedited manuscript, dated back at the last part of 1932 and titled Urassoziation und Zeitigung: Konstitution des realen, Raum, Zeit, Kausalität ${ }^{8}$. According to the incipit of the manuscript (p. 2):

Zu der schwierigen Klärung der offenen Horizonte, die sich in Gang des monadischen Lebens immerzu konstituieren, und die zugehörigen Schwierigkeiten „möglicher Erfahrung" ist folgende zu bedenken. Die ursprünglich zeitigende Assoziation (die Retention

8 Edmund Husserl's manuscripts have been consulted at the Husserl-Archiv of Freiburg im Breisgau, during the winter semester 2016/17 (from October 2016 to February 2017), with prior authorisation from the Director Prof. Dr. Hans-Helmuth Gander. The manuscript we will here quote has been classified under the signature D 15, and has been transcribed in a typescript by M. Biemel. It was delivered to the Archiv on 8 December 1951. The transcribed manuscript consists of 45 pages. Page 7, 24, 33 present respectively the dates of 1, 2 and 3 November 1932. The dating of pages 1-6 remains uncertain. One could translate the title of the manuscript (attributed to it by Biemel) as follows: Original association and temporalization: constitution of reality, space, time and causality. 
und Vorzeitigung) geht an jedem Datum als Einheit einer Abgehobenheit [...] vonstatten. [...] Was aus der Urimpression hervorgegangen ist, hat nur für mich „Sein“ als die jeweilige „momentane“ Retention, bei der Konstitution der Dauer habe ich einen impressionalen Punkt [...] und eine Querreihe, die kontinuierlich abgewandelten Retentionen der früheren urimpressionalen Phasen. Das Selbst im Strömen und in Selbstdeckung. Das Ganze versinkt, wenn die Kontinuität der Urimpression unterbrochen ist $[\ldots]^{9}$.

The intentional life of the concrete ego displays a founding synthesis. The clarification of this original, operative unity is the final aim of phenomenological reflection. The beginning of such reflection consisted in a critical movement. This movement consists of a suspension of the unjustified belief in the positivity of facts and in a reduction to a self-evident knowledge, starting from which the phenomenologist should progressively bring out in clarity the intentional operativity that structures living experience in the way it de facto is.

Husserl describes the supposedly original synthesis as a temporal one. Every possible experience is defined by the unity of a primordial presence with the retentional continuity of consciousness. In the context of this synthesis, one can still distinguish a determinans (the serial structure of time) and a determinandum (the Urimpression). However, the justification of the supposedly original, founding aspect of this synthesis implies a relevant addiction to this distinction. This addiction consists in a character of continuity, not only (as it is for other constituted temporal syntheses) for what pertains to the formal aspect (i. e. between the "now" and the retentional "no more"), but also for what concerns the Urimpression. The material presentation of the Urimpression to consciousness in the "now" (Jetzt), deemed as contingent in relation to the temporal constitution of determinate intentional objectivities, is, at this original level, necessarily required in order to prevent the collapse of the entirety of experience as an intentional structure. The rise of the totality of experience as a transcendental logical structure demands a certain a priori unification of the absolute hyletic multiplicity that is facticity. On the other hand, transcendental reflection should be able to grasp this absolute sense of facticity only via negationis, as a difference from form (and thus from unity as such).

9 "For the difficult clarification of the open horizons, which always constitute themselves in the course of the monadic life, and the associated difficulties of 'possible experience', the following is to be considered. The original temporal association (retention and pre-temporalization) takes place in respect of each datum as unity of a separation. [...] What emerged from the original impression has only for me 'being' as the respective 'momentary' retention, [while] in the constitution of duration I have an impressional point [...] and a transversal series, the continuously modified retention of the earlier original impressions. The self in streams and in self-concealment. The whole sinks, if the continuity of the original impression is interrupted [...]”. Translation is mine. 
The peculiar "streaming punctuality" of the living present, apparently an elaboration of the psychological concept of "extended present" (Husserl, 1969, 19-23), is in fact a necessary work hypothesis, given Husserl's attempt at a phenomenological investigation regarding the absolute transcendental origin of experience. This is because the required continuity of the Urimpression cannot be made discreet by the dimensionless punctuality of the Jetzt-form, and yet it needs to partake in a certain synthetic relation with consciousness, in order to be able to define in a formal sense the field of possibility of every possible experience. The manuscript continues (p. 7-8):

Natur als Universum der Realitäten hat universalen Formen der Zeitlichkeit nach Simultaneität und Sukzession, in der die Realitäten, die seienden Körper, sind. [...] Genauer besehen hat die Welt und zunächst in unserer abstraktiven Beschränkung die universale körperliche Natur eine konkrete Form, die sich abstraktiv in folgender Weise schichtet. In äußerster Abstraktion ist die Natur eine Allheit zeitlich Seiender, und zwar eine Allheit im zeitlichen nacheinander Verharrender, d. i. in der sukzessiven Zeit Fortdauernder ${ }^{10}$.

This is an instance of transcendental philosophy's attempt at a priori foundation of the science of nature via an abstract, supposedly essential determination. In a phenomenological perspective, the enigmatic relation between ideality and factuality can be read indeed as the relation between truth and time (Paci, 1961, 3-22) ${ }^{11}$, with the phenomenological task being to describe and clarify the articulation of the former into the horizon of the latter. Therefore, the assumption of time as the original field of every possible truth means the exclusion of any eventual non-temporal truth that should supposedly partake in temporal experience (implying that forms are properly omnitemporal, rather than atemporal). If the equivalence between foundation and condition of intelligibility is a general character of such attempt, then the position of a temporal synthesis as a condition of intelligibility of every possible experience is

10 "Nature as the universe of realities has universal forms of temporality in accordance with simultaneity and succession, in which the realities, the existing bodies, are. [...] More exactly, the world and, first of all, in our abstract limitation, the universal physical nature has a concrete form, which layers itself abstractly in the following way. In the utmost abstraction, nature is a totality of temporal beings, and indeed a totality in a temporal succession, i. e. in the successive continuous time". Italics added, translation is mine.

11 Paci's dialectical conception of phenomenology is based exactly on the irreducibility of time into truth (and vice versa) - that is, on the irreducibility of the contingency of actual facts into a certain logical determination (and vice versa). Each one of these terms implies the other, as facts cannot be given outside a determined experience, and an experience is the fact of a living consciousness in itself. Thus, it is possible to interpret phenomenology - i. e., transcendental philosophy in its most radical instance - as an infinitely unresolved dialectic movement of reflection between "truth" and "time" within the intentional object. The arguments developed here hint at this possibility. 
in fact a testimony of the radicalism of Husserl's phenomenology as transcendental philosophy.

However, the justification of time-synthesis as the form of nature as such implies once again an ambiguous duality. This synthesis defines the "concrete form" of life-world - that is, life-world as clarified in its essential structure. This concrete form should fill the gap between reflection and complete experience. It is metaphysical as far as there is no possible experience (i. e., no possible intentional constitution) of a concrete form of nature, since the reflexive determination of a form presupposes a certain abstraction from facts.

The admission of a de jure possible intuition of the totality of nature, albeit only as a formal temporal horizon, remains unaltered in its metaphysical character even admitting that such intuition is never de facto actual. The infinity that this intuition entails, as far as it is a priori founded in the metaphysical indistinction between form and matter that is the living present, defines the founding character of this intuition. In other words, this intuition defines the origin of possible experience specifically by virtue of its non-actual aspect. This clearly results from the manuscript itself ( $\mathrm{p}$. 21-23):

Nicht Erfahrung, sondern „Anschauung“ ist notwendig, damit den zweifellosen Boden zu gewinnen, auf den alle rechmäßigen Begriffe und Urteilsbildungen über Welt und Natur angewiesen sein. [...] Diese Vollkommenheit der wirklichen Erfahrung, die in allem wirklichen synthetischen Fortgang immerfort endlich bleibt, ist in eben dieser Endlichkeit nie zu gewinnen und a priori. Was aber zu gewinnen ist oder sein muß (wenn ja ein Axiom der Natur aussprechbar sein soll) ist die Vollkommenheit einer „Anschauung“, welche die endliche Ausgangserfahrung in die Totalität ihrer Möglichkeiten verfolgt und das Erfahrene als möglicherweise Seiendes in der Einstimmigkeit eines möglichen Fortganges des Erfahrens konstruiert ${ }^{12}$.

In this perspective, the actuality of experience implies its contingency, i. e. its specific placement in the articulated totality of possible experience. It follows that the intuition of the living present can define the formal a priori dimension of this totality only insofar as it does not, in its turn, take place into this same dimension - that is, only as long as it is (at least partially) not actual.

12 "Not experience, but 'intuition' is necessary in order to gain the indubitable ground which all legitimate concepts and judgments about world and nature depend upon [...]. This perfection of actual experience, which remains always finite in all actual synthetic progress, can indeed never be attained in this finitude and is a priori. But what is or has to be gained (if an axiom is to be pronounceable with regard to nature) is the perfection of an 'intuition', which pursues the finite initial experience into the totality of its possibilities and constitutes the experienced as possibly existing in the concordance of a possible continuation of the [already] experienced". Italics added, translation is mine. 


\section{CONCLUSION}

I presented two examples in favour of two specific points. The first point is that an a priori knowledge of nature (i. e. of what there factually is) implies a foundation only achievable through the dissolution of the distinction between matter and form. The second point is that such an indistinction cannot be dealt with within the domain of transcendental philosophy - that is, within the domain of the reflexive analysis of experience. On other aspects, even deeply linked to this points (such as the question about if and how the idea of an infinite progression towards the end of phenomenology already involves such metaphysical completion, or if its heuristic value could be somewhat considered independently from it), I do not express myself here.

It is worth noting, once again, the subtlety of Kant and Husserl's theoretical operations. The metaphysical aspect of these operations does not consist in the abstraction of a simplified model of nature as such, but rather of the claim to essentiality that the abstracted determination holds towards what remains of facticity. From transcendental philosophy's point of view, such a claim results in an attempt at an a priori (i. e. universal, formal, necessary and ideal) foundation of the intelligibility of nature by this determination.

In Husserl's case, actual life is already conceived as essentially convergent towards the intuition of life-world, while the same intuition seems to emerge spontaneously from the actuality of life itself. This problematic correspondence should serve to define factuality as a totality, unified within this a priori intuition.

If we assume phenomenology as the most radical and elaborated instance of transcendental philosophy, the acknowledgement of the metaphysical nature of its take on the foundation of the science of nature requires one last consideration. We have seen that a transcendental attempt at an a priori foundation of our knowledge of facts implies, as long as it remains within the context of transcendental reflection, a non-formalizable - non reducible to an essential form, or non-convergent towards it, so to say - aspect. This does not exclude the possibility of an a priori foundation of facticity, in the eventuality of a proper redefinition of the notion of "a priori knowledge". Such a redefinition would have to dissolve the connection between a priori knowledge, universality, formality and necessity. It would be based on a contingent abstraction from the absolute multiplicity of actual facticity - the multiplicity that, from the point of view of formalizing reflection, remains each time as a material residue. 


\section{REFERENCES}

Aristotle. (1831). Aristoteles Graece ex recognitione Immanuelis Bekkeri. Volumen prius. Berlin: Berolini.

Benjamin, W. (1985). Gesammelte Schriften. Bd. VI. Frankfurt am Main: Suhrkamp.

Bunge, M. (1967). Foundations of physics. Berlin, Heidelberg: Springer.

Derrida, J. (1993). La Voix et le Phénomène: Introduction au problème du signe dans la phénoménologie de Husserl. Paris: Presses Universitaires de France.

Falcon, A. (2005). Unity without Uniformity: Aristotle and the Science of Nature. Cambridge: Cambridge University Press.

Heelan, P. A. (1987). Husserl's Later Philosophy of Natural Science. Philosophy of Science, 54 (3), 368390.

Held, K. (1966). Lebendige Gegenwart. Die Frage nach der Seinsweise des Transzendentalen Ich bei Edmund Husserl, Entwickelt am Leitfaden der Zeitproblematik. Den Haag: Martinus Nijhoff.

Hintikka, J. (1992). Kant on the Mathematical Method. In C. J. Posy (Ed.), Kant's Philosophy of Mathematics. Modern Essays (21-42). Dordrecht, Boston, London: Kluwer Academic Publishers.

Husserl, E. (1954). Die Krisis der europäischen Wissenschaften und die transzendentale Phänomenologie. Den Haag: Martinus Nijhoff.

Husserl, E. (1969). Zur Phänomenologie des inneren Zeitbewusstseins (1893-1917) (Hua X). Den Haag: Martinus Nijhoff.

Husserl, E. (1970). The Crisis of European Sciences and Transcendental Phenomenology. An Introduction to Phenomenological Philosophy. Evanston: Northwestern University Press.

Husserl, E. (1973). Cartesianische Meditationen (Hua I). Den Haag: Martinus Nijhoff.

Husserl, E. (1974). Formale und transzendentale Logik. Versuch einer Kritik der logischen Vernunft (Hua XVII). Den Haag: Martinus Nijhoff.

Husserl, E. (1976). Ideen zu einer reinen Phänomenologie und phänomenologischen Philosophie. Erstes Buch. Allgemeine Einführung in die reine Phänomenologie (Hua III/1). Den Haag: Martinus Nijhoff.

Husserl, E. (1984). Logische Untersuchungen. Zweiter Band. Erster Teil. Untersuchungen zur Phänomenologie und Theorie der Erkenntnis. In zwei Bänden (Hua XIX/1). Den Haag: Martinus Nijhoff.

Husserl, E. (2001). Die „Bernauer Manuskripte“ ̈̈ber das Zeitbewußtsein (1917/18) (Hua XXXIII). Dordrecht: Kluwer Academic Publishers.

Kant, I. (1781). Critik der reinen Vernunft. Riga: Johann Friedrich Hartknoch.

Kant, I. (1902). Vorkritische Schriften I: 1747-1756. Berlin: Reimer.

Kant, I. (1904). Kritik der reinen Vernunft. Berlin: Reimer.

Kant, I. (1911). Kritik der reinen Vernunft (1. Aufl. 1781), Prolegomena, Grundlegung zur Metaphysik der Sitten, Metaphysische Anfangsgründe der Naturwissenschaft. Berlin: Reimer.

Kant, I. (1936). Opus Postumum. Erste Hälfte. Berlin: De Gruyter.

Kant, I. (1938). Opus postumum. Zweite Hälfte. Berlin: De Gruyter.

Kant, I. (1942). Bemerkungen zu den Beobachtungen über das Gefühl des Schönen und Erhabenen, Rostocker Kantnachlass, Preisschrift über die Fortschritte der Metaphysik. Berlin: De Gruyter.

Kant, I. (2004). Metaphysical Foundations of Natural Science. New York: Cambridge University Press.

Kern, I. (1964). Husserl und Kant. Eine Untersuchung über Husserls Verhältnis zu Kant und zum Neukantianismus. Den Haag: Nijhoff. 
Paci, E. (1961). Tempo e verità nella fenomenologia di Husserl [Time and Truth in Husserl's Phanomenology]. Roma, Bari: Laterza. (in Italian).

Pecere, P. (2009). La filosofia della natura in Kant [Kant's Philosophy of Nature]. Bari: Edizioni di Pagina. (in Italian).

Ryckman, T. (2005). The Reign of Relativity: Philosophy in Physics 1915-1925. New York: Oxford University Press.

Tengelyi, L. (2005). Experience and infinity in Kant and Husserl. Tijdschrift voor Filosofie, 67 (3), 479500.

Toraldo di Francia, G. (1981). The investigation of the Physical World. Cambridge: Cambridge University Press. 